\title{
Samurai and Peasants in the Civil Administration of Early Modern Japan
}

\author{
Kenichiro Aratake
}

What role did samurai play in the functioning of civil administration in early modern Japan, and how did they interact with peasants in the areas they were charged with supervising? Did the administrative organizations under the feudal lords (the shogunate and domains) employ a large number of samurai, and what did they contribute to the governing of rural areas? The answers to these questions are important for thinking holistically about the provision of public goods by the feudal lords, as well as for gaining a more concrete understanding of the allocation of human resources.

In early modern Japan, the shogunate and domains collected land levy called nengu (annual tributes) ${ }^{1}$ from commoners, out of which the samurai's salaries were paid. This system of public finance gave rise to two obligations in the relationship between feudal lords, retainers (samurai), and commoners (Ravina 1999). The first obligation is that, in order to pay retainers' salaries, feudal lords levied tributes on commoners; the second is ethical in nature: feudal lords were to act with mercy toward commoners. This is the starting point for understanding the civil administration and society of early modern Japan and the relationship between feudal lords and subjects. The topic we expand is the ways samurai and peasants were involved in tribute collection and in the governance of the domain. Collection of the annual tribute was based on a cooperative effort between samurai and the peasants who were delegated to represent their village communities.

Let us begin with an examination of who was appointed to the civil administration and what roles they played. Did the samurai play a leading role in the departments of civil administration, which were created to facilitate the domain's rule of rural areas, or did the representatives of the peasants take the lead? One of the key 
steps in administration was the cadastral survey, which registered land holdings, which were the basis for assessment of annual tribute. Though it would not have been strange for the samurai to assume all roles in conducting the surveys, as the surveys primarily served the interests of the lords, peasants were actively involved as well. A second question involves the domain's attitude toward civil administration as reflected in its staffing, the proportion of samurai in the domain's vassal band involved in the civil administration. Finally, the answers to these questions tell us about the relationship between the nature of the participation of samurai in the civil administration and the regions they ruled.

\section{RULER AND SUBJECT: THE RELATIONSHIP BETWEEN SAMURAI AND PEASANTS}

Under the rule of the Tokugawa shogunate, which lasted from the seventeenth century to the second half of the nineteenth century, Japan was divided among about 250 domains. Although each domain, in principle, had autonomy over the management of its revenue and expenditure, the organization and rules that applied to the villages were similar to the structure employed in the territories under the direct rule of the Tokugawa shogunate. All domains had a local intendant's office, to which the samurai belonged, and this office appointed a group of village officials, which mostly comprised local villagers. The structure by which domains ruled villages, therefore, involved the participation of both samurai and peasants, and in nearly all domains, interaction in administration created relationships between samurai and peasants. The samurai and peasants composing the group of village officials were responsible for collecting tributes and maintaining the public order. The Okayama domain can serve as an example of how samurai and peasants were organized within the civil administration (Taniguchi 1964).

In the "Samurai" structure of Okayama domain, the county director (gundai, referring to a director general) was at the top of a village's judicial system; there were a maximum of two director generals. This post, which was created by the rural administrative reforms of $1682,{ }^{2}$ was filled by what at first were called "experts in village administration" (jikatakōsha). Appointed under the county director were officials called county magistrates (kōribugyō). It is unknown when this post was established, but it existed before the creation of the county director. Originally, there were four magistrates, and they lived in the castle town district (Jöka-machi), but in 1654 their number was increased to eleven and they were moved to the counties they were to administer. The reforms of 1682 reduced their number once again to four. From then until the end of domain rule in 1871 , the county magistrates lived at their residences in Minamigatamura, on the outskirts of the Joka-machi of Okayama Castle, and commuted to the county office, which was in the Jokka-machi. Under this system of village administration, the county director was something of a figurehead position, with the real power being held by county magistrates. 
The chief duty of the county magistrates was the oversight of all aspects of rural governance; their specific duties were (a) determining annual tribute amounts, (b) conducting twice-yearly village inspections, ${ }^{3}$ (c) appointing village officials, ${ }^{4}$ and (d) informing villages of laws promulgated by the Tokugawa shogunate and by the domains, among other things. The post of county inspector (körimetsuke) was also established in 1682, to be filled by five people. In the beginning, each inspector was assigned to his respective area; however, after 1789, all five inspectors shared jurisdiction over the entire domain. The job of county inspector was to monitor everyone, from the samurai under the county magistrates to peasants in the most far-flung villages. According to the regulations established by the domain, the county inspectors were responsible for examining the working conditions of county magistrates and the local administrator (muradaikan) and the farming and living conditions of the peasants. While it may have been possible for them to monitor the small number of samurai engaged in village administration, it would have been very difficult in practice for five officials to survey and monitor the approximately 350,000 peasants in the more than seven hundred villages under their jurisdiction. ${ }^{5}$ The local administrators were the samurai who were closest in position to the subjects of the domain. Their numbers decreased over time from fifty-four in 1654 to thirty-four in 1676, and finally to twenty-six in 1682 . They took orders from the county magistrates and were originally responsible for communicating a wide range of messages to the villages, but a decree in 1682 limited their role to carrying out the religious inquisition ${ }^{6}$ and to duties related to the annual tribute. These annual tribute duties, however, consisted of drafting measures to boost agricultural production, which had been waning since the latter half of the eighteenth century, and do not necessarily signify their actual involvement in the collection of annual tributes.

This concludes the description of the organization of the samurai in village administration and the changes in their posts, appointments, and official duties. Aside from the fact that the positions of county director and county inspector were newly created in 1682, there was a clear decrease in the overall number of samurai assigned to all of the official positions from county director through local administrator. From the end of the seventeenth century until the end of domain rule in 1871 , no more than forty or so samurai ruled Okayama domain's 350,000 peasants and, although village management was ostensibly their primary duty, the number of samurai who actually visited villages was fewer still. It is difficult to imagine that they managed to fulfill the monitoring and surveying responsibilities stipulated in the feudal decrees. However, before it can be concluded that there were not enough samurai in village administration, it is necessary to consider how their subjects, the peasants, were organized.

The administrative unit of rural areas in early modern Japan was the village, and the "Big Three" village officials (murakata sanyaku), consisting of village headman (shōya, nanushi), vice headman (toshiyori, kumigashira), and peasants' 
representative(goningumi-gashira, hangashira), played leading roles in the administration. In the Okayama domain, when the rule of the Tokugawa shogunate was established in 1603, the Big Three were called shoya (village headman), toshiyori (vice headman), and goningumi-gashira (peasants' representative). In 1689 these titles were changed to nanushi, kumi-gashira, and han-gashira. ${ }^{8}$ The typical procedure was for each village to choose its officials and subsequently obtain the county magistrate's approval for their appointment.

Among the Big Three, the most important role belonged to the village headman, who either inherited the post or was voted in by peasants in an election (irefuda). ${ }^{9}$ Most villages had one village headman, but some large villages of one thousand $k o k u^{10}$ or more appointed two. In contrast, some village headman served double duty for two smaller villages (five hundred koku or less). The Okayama domain encompassed approximately seven hundred villages, so we can estimate that there were roughly 750 village headman, based on the proportion of large and small villages. The duties the village headman fulfilled during the Edo period are enumerated in historical records compiled in Okayama during the Meiji period. They were (a) to gather the annual tributes collected from individual peasants, (b) to create records about the villages, and (c) to oversee general affairs in the villages. The role of vice headman was to assist with these duties. There were usually two vice headmen appointed to a village so we can estimate that the number of vice headmen was approximately fifteen hundred across the entire Okayama domain. Finally, villages did not have a fixed number of peasants' representatives; rather, it was stipulated that there should be one peasants' representative for dozens of households, to be determined by an election within the village. The fact that they were elected as peasants' representatives meant that they served as village inspectors in addition to participating in village administration under the headman and vice headman.

One of the important duties of these village officials was to collect the annual tributes levied on peasants in the village and deliver them to the domain. If a peasant could not pay the annual tribute, it was stipulated that the village would be held collectively responsible for payment (Shirakawabe 2010). Evidence for the important role that the village officials played in paying these annual tributes to the domain is contained in the records they kept. Previous research shows that the village officials had to become proficient in the creation of "administrative documents," which gave them a strong sense of responsibility toward village administration (Kurushima 1995). Certainly the historical materials that were passed down from the houses of village headmen include many documents about annual tributes and substantiate the claim that village officials took the initiative in performing this role. Furthermore, Miyaoi Yasuo, an author who had firsthand experience as a village headman in the early nineteenth century, wrote in one of his books that "village headmen selflessly devote themselves to village administration, for which not only the precise calculation of annual tributes, but also the careful maintenance of village records" is of utmost importance (Watanabe 1989). 
Above the village officials were the ojōya ${ }^{11}$ (representative of the village headman); five to fifteen ojoya were chosen to represent multiple villages. ${ }^{12}$ In the Okayama domain, sixty-three ojōya were appointed in 1701, with roughly similar numbers being appointed after that. Their main duty was to represent their villages in direct negotiations with samurai; this, in effect, connected villages to the administration of the domain.

From this description we can see that some forty or fifty samurai were appointed to posts in village administration and that 3,750 village officials ${ }^{13}$ composed the peasants' side of the administration. These numbers also seem to indicate a declining trend in the numbers of samurai in charge of civil administration from the seventeenth to the eighteenth centuries. The domain's acceptance of fewer samurai in village administration is surely due, at least in part, to the growth of village organizations made up of peasants.

The heavy burden assumed by the village headmen and others and the limited involvement of the samurai suggest that the samurai could not fully grasp the local areas' administrative issues. The next question that arises is how this impacted the collection of annual tribute and the roles of samurai and the peasants in collection.

\section{CADASTRAL SURVEYS AND LOCAL INSPECTIONS BY SAMURAI}

The annual tributes collected from peasants, compiled by village officers, and paid to feudal lords (the shogunate or domains) were calculated according to data collected in cadastral surveys conducted by the rulers. What roles did the samurai and peasants play in carrying out these cadastral surveys?

Land surveys were conducted in many villages under the command of rulers, and in the second half of the sixteenth century they were used to calculate annual tributes. These surveys began with the Taikō survey, which was actively pursued under Hideyoshi Toyotomi's rule. This was followed by the Tokugawa shogunate's Keichō survey in the first decade of the 1600 s, which was nationwide in scale; the Kanei-Keian survey during the 1630s and 1640s; and the Kanbun-Enpō survey ${ }^{14}$ during the 1660 s and 1670s, which focused on the shogunate's territory in Kanto and Kinai, to name just a few. In contrast to these surveys, which were carried out by the shogunate, domains sometimes conducted surveys themselves within their own territories. However, from the end of the seventeenth century until the Meiji Restoration, hardly any large-scale surveys were conducted by the shogunate or domains.

The process of conducting a survey was as follows: (1) determine the boundaries of the village, (2) measure the area of the village's land according to zones defined by usage (e.g., rice field, vegetable field, housing, and so on), (3) assess the agricultural yield of each zone based on the fertility of its soil, ${ }^{15}$ and finally (4) identify the owners of the plots of land thus measured and assessed. The names 
of these individual landowners from whom annual tributes were collected, along with the agricultural output assessments, were then documented in a cadaster ${ }^{16}$ for that village. Analyses of land surveys in many historical studies have been based on these results, with the assumption that the villages were surveyed by the ruler's vassals (Watanabe 2004). However, surveying all the farmland in Japan required extensive manpower and was very expensive; thus, many surveys could be conducted only once. Furthermore, while the domain did send samurai to villages to conduct surveys, the work could not have been completed without the help of the village headmen, who were familiar with the villages (Watanabe 2008).

From 1640 to 1643 , a "General Survey" was carried out across all rural areas in the Sendai domain in the Tohoku region ${ }^{17}$ (Sendai-shi 2001). The survey was prompted by, among other factors, the loss of the previous survey books in a fire in 1636 in the office where the domain's administrative records were kept, and heavy damage incurred to rural areas by major flooding throughout the domain in 1637 . The Sendai domain sent 160 samurai in thirty-five groups ${ }^{18}$ from the castle town to villages. Armed with specialized techniques for land measurement and assessment, these samurai were tasked with conducting the survey and recording their findings. To do so effectively, however, would have required the guidance of the village officials, who were knowledgeable about village affairs, as well as the participation of peasants, who could help with small tasks. The precise number of peasants mobilized for the Kan'ei-era survey is unclear, but their cooperation was surely indispensable for a mere 160 samurai to survey one thousand villages (Watanabe 1983).

Moreover, the Tokugawa shogunate's Kanbun-Enpō survey conducted around Osaka can serve as a reference for estimating the proportion of samurai and peasants participating in cadastral surveys (Mori 1970). The neighboring domains of the shogunate's territory, who were in charge of the task instead of the shogunate's officials, sent their vassals to the villages targeted for the survey, and for each ten samurai the village enlisted the participation of twenty people, including village officials. Conducting cadastral surveys was important not only for the rulers (shogunate and domains) to collect annual tributes, but also as recognition of the domain's authority in the villages. In addition, because surveys could not be conducted frequently, they were a rare opportunity for samurai to set foot on peasants' lands. However, in practice, very few samurai were actually dispatched, and thus they needed the help of the peasants as a matter of course.

While the collection of annual tributes was based on large-scale cadastral surveys conducted by the shogunate and domains that focused on existing fields, there was also an established rule throughout the country stipulating that agricultural land that had been expanded through the development of new fields was also to be registered in the cadasters, in a system called takaire. The Hiroshima domain in the mid-eighteenth century provides evidence for considering the relationship between samurai and peasants in the basic takaire system (Hiroshima-ken 1973). 
Once a newly developed field in a rural area became capable of sustaining production that was equally as stable as existing fields, ${ }^{19}$ the village headman recorded its land area and projected yield in what was called a "preliminary inspection book" and submitted it to the county magistrate. ${ }^{20}$ Upon receiving the document, the county magistrate would check to see if it followed the correct format, without going to inspect the field directly. If he deemed it correct, the county magistrate approved the takaire registration of the new field and issued a directive to the village headman to pay annual tribute of $50 \%$ of its projected yield for the next five years. Since the figures written in the preliminary inspection book were, above all, estimated yields, the actual yields over its initial five-year tribute-exempt period were checked, ${ }^{21}$ and their average was registered as the official number in tributerelated documents such as the cadastral. That is the process by which new agricultural land in the Hiroshima domain was registered as official territory: the village headman undertook land inspection and documentation from the very beginning, whereas the county magistrate (responsible on the domain's side) merely received the document and made decisions based on it without verifying it.

However, the county magistrate and his subordinate samurai did tour the area under their jurisdiction every year under a system called junken, which, in the Hiroshima domain, was defined as follows. First, every March, the county magistrate was to visit the villages under his jurisdiction to verify village affairs firsthand. March was chosen (a) to ensure that the peasants were preparing for the upcoming rice planting season and (b) to motivate peasants to work hard at farming. The magistrate's subordinate administrators ${ }^{22}$ were also to conduct village inspections at least twice in total over the spring and summer every year. The purpose of the administrators' inspections was to ensure that crops were growing normally. If a crop failure was forecasted due to the weather, measures such as tribute abatement needed to be taken to adjust for the poor rice harvest in the fall. It was this predictive ability that was sought in an administrator. All together, there were to be three inspections per year in the Hiroshima domain, conducted by samurai in the civil administration, and it is probable that other domains generally had a similar rule. But did samurai in the Hiroshima domain actually make the rounds they were supposed to? Excluding years when there were major natural disasters such as droughts and floods, samurai did not visit villages more than once a year or so. Rather than inspecting villages themselves, it became the norm for the country magistrate and administrators to implement laws relating to the village based on reports submitted by village headmen. Even in the case of annual tributes, which are of utmost importance in feudal rule, village headmen and other officials collected grain from individual peasants and delivered it to the domain office. The county magistrate thus came to depend on the peasants for his work.

From the perspective of cadastral surveys and annual tribute collection, which are central issues in rural administration, the preceding analysis of the samurai's and peasants' roles shows that the role of the samurai was even smaller than previously 
thought, which leads to the conclusion that their duties were proactively handled by the village headmen and other peasants. How, then, did civil administration in rural areas come to be dependent on the peasants? The self-reliance of villagers who performed all of the basic work involved in administration has been cited as one reason (Kurushima 1995, Watanabe 2010). Village headmen and village officials accumulated knowledge about village management, increased efficiency, particularly in duties that had become routine work, and worked toward maintaining good relations with the feudal rulers. ${ }^{23}$ Taking into account the structure of organizations in the Okayama domain along with the distribution of work between the samurai and peasants as described for the Hiroshima domain here, it is apparent that the rulers did not need to appoint a great number of people from their side. This leads to the next question, what proportion of samurai were involved in civil administration?

\section{THE POSITION OF THE CIVIL ADMINISTRATION IN VASSAL BANDS}

\section{The Organizational Structure of the Vassal Band in the Hiroshima Domain}

The average percentage of the population holding the rank of samurai is estimated at about $6 \%$ nationwide, though there were domains with higher percentages, such as Sendai with 23\% (Morris 2009). In the Hiroshima domain, there was a total population of approximately 910,000 in 1869 as the domain system was approaching its end, just over fifty-six thousand were samurai. ${ }^{24}$ That puts the percentage of samurai in the total population at $6.2 \%$, roughly on par with the national average (Hiroshima-ken 1984). Though these numbers cannot be precisely verified because of the nature of available statistics, there was a vassal band in the second half of the eighteenth century predominantly comprising about four thousand close attendants ${ }^{25}$ to the ruler.

The organizational structure of the vassal band in the Hiroshima domain is shown in figure 3, along with the respective numbers of samurai who held each post in 1753 and 1862. These numbers should be understood to represent the upper echelon, ${ }^{26}$ those who were superior in rank to the ruler's aforementioned four thousand close attendants. At the very top was the ruler (daimyō), and directly under him were the chief vassals: elders (karō), chief directors (toshiyori), and chief inspectors (ómetsuke), in that order. Second in command to the ruler, the elders oversaw the domain administration and vassal band. Next in line, the chief directors' role was to take directives from the elders and issue instructions accordingly to the specialized departments, whose roles are described later. Finally, the chief inspectors, despite their title, composed the remainder of the core of the domain administration along with the elders and chief directors. There were no great changes in the numbers of these chief vassals between 1753 and 1862 except for the chief inspectors, whose numbers increased. 


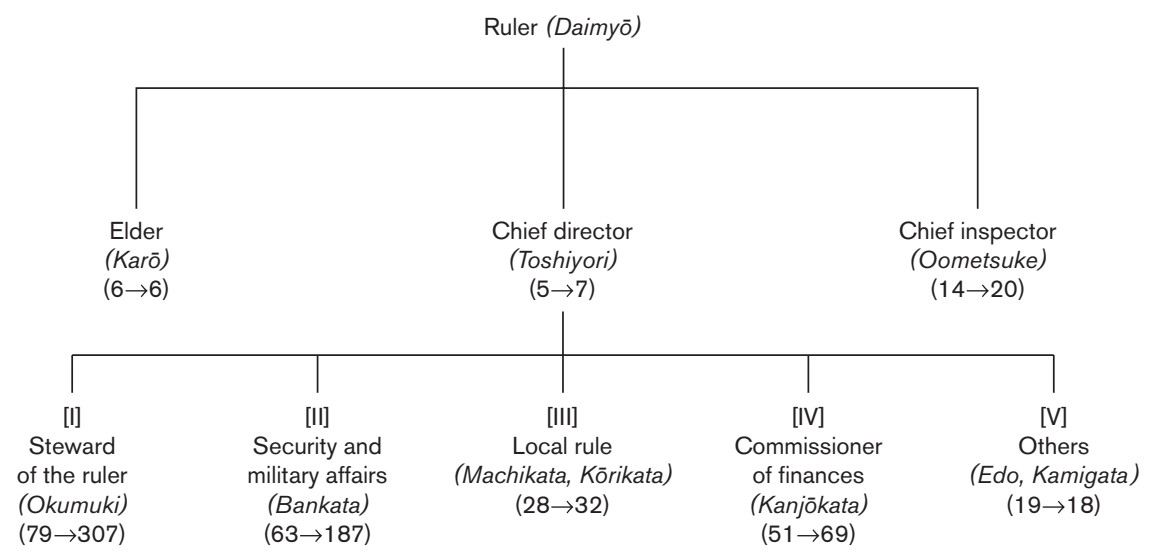

FIGURE 3. Hiroshima Organizational Formation of 1753 and 1862

Source: Hiroshima-ken 1984.

Note: Numbers in parentheses denote the change from 1753 to 1862.

Under the chief vassals were five specialized departments: (1) "steward of the ruler," which dealt with various tasks on behalf of the ruler; (2) "security and military affairs," the department that defended the castle and the territory; (3) "local rule", the samurai engaged in the work of governing towns and villages as government officials; (4) "commissioner of finance," the department that dealt with fiscal issues, comparable to present-day financial departments; and finally (5) "others," including samurai who lived in Edo, Kyoto, and Osaka permanently as government officials. ${ }^{27}$

The numbers under each section denote the numbers of samurai included therein. Let us consider the changing pattern of these numbers. In 1753, 304 out of four thousand samurai held posts of elder or below. Then in 1862 the number of samurai holding official posts, which had remained steady at around three hundred for over a century, skyrocketed. This was because, during the nineteenth century, each domain attempted to expand its army to face the international crisis in Japan. As table 3 indicates, this entailed the near-quadrupling of those attached to the Office of the Ruler and a threefold increase in the section charged with security and military affairs. However, the numbers of samurai in the other three departments remained the same, suggesting that the ruler was actively looking to strengthen the military and augment his staff of close attendants.

An analysis of the "public office work" conducted in 1862 found that a total of 268 people were employed as close attendants, forty-five worked for the commissioner of finance, and thirty-two were in civil administration. These close attendants served the domain ruler and his family, and performed everyday chores. They also included doctors who provided medical treatment to the ruler. The commissioner of finance's office managed the domain's finances and oversaw the 
production of wood, paper, iron, and salt. It also managed finances for merchants and peasants. Civil administrators assessed annual tribute collections and implemented related laws in the villages.

What can be inferred from these numbers? First, the domain ruler had an overwhelming number of close attendants, whereas there were only a small number of employees in the offices of commissioner of finance and local rule. In addition, because of the sankin-kōtai system, it had become the ruler's duty to live in his Hiroshima castle and the Edo capital each for two years at a time. Therefore, there must have also been a large number of people accompanying the ruler who also had to go back and forth between Hiroshima and Edo. The retirement of a ruler presents another point to consider. When passing the position of ruler down to a successor, the retiring ruler typically built himself a retirement mansion. However, after the mansion had been built, close attendants would be employed to serve the retired ruler, creating a situation where there were effectively not only "two rulers" but also a dual structure in personnel and funding.

This concludes the discussion of the characteristics of the vassal band in the Hiroshima domain. Though the numbers of samurai appointed to posts in 1753 and 1862 were influenced by historical circumstances, the structure of the vassal band indicates an emphasis on roles for serving the ruler and his family, followed by posts relating to the military, especially in accordance with the situation near the end of the Edo period. In contrast, the proportion of those who were involved in civil administration was rather small.

\section{The Proportion of Samurai in Civil Administration Relative to the Rural Population}

Let us consider the civil administration from another angle. Table 3 contains information about four of the Hiroshima domain's seventeen counties in 1715, beginning with agricultural output, the numbers of villages and households, and their overall population. The middle columns of the table show the number of town magistrates or county magistrates engaged in administrative work in each county, as well as the number of local administrators, ${ }^{28}$ who were burdened with substantial work. In total, the Hiroshima domain had twenty-seven county magistrates and town magistrates, and seventy-five local administrators who performed actual local administration duties. According to the "local rule" section of figure 3, there were twenty-eight county magistrates and town magistrates in 1753, so their numbers hardly changed from 1715. There were also seventy-five subordinates to the local rule division, though they are not indicated in figure 3. Area 1, "Villages around Hiroshima," refers to the villages in the direct vicinity of the castle town (Jöka-machi) of Hiroshima. There were seventeen such villages, containing a total of 893 households and a total population of approximately ten thousand. ${ }^{29}$ Unlike the remaining counties in the table, this area had no county magistrate, because 


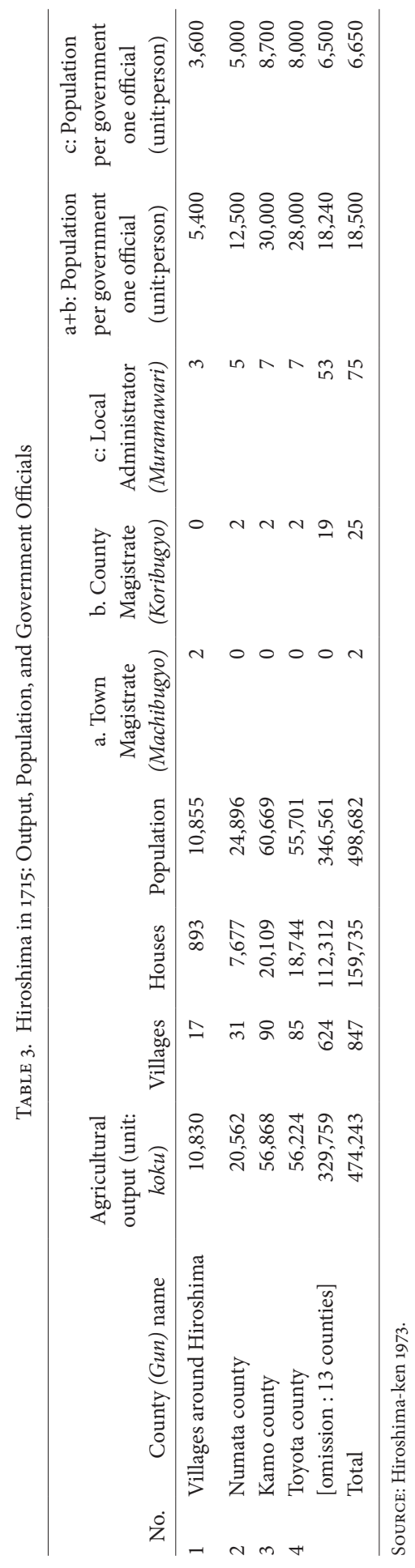


it was under the jurisdiction of the town magistrate, who was in charge of the castle town. The three local administrators were thus under the town magistrate's command. The final two columns of table 3 show the population of each county per magistrate and per administrator, which was fifty-four hundred and thirty-six hundred, respectively, for area 1 . Area 2 was the smallest in scale of all the counties; areas 3 and 4 were the largest.

Let us look at Toyota County (area 4) as an example. This county was about fifty-six thousand $k o k u$ in size and contained eighty-five villages, eighteen thousand households, and fifty-five thousand people. Two county magistrates and seven local administrators were responsible for its governance. The tendency for this county and all of the others was to have a fixed number of two county magistrates and to adjust the number of local administrators according to the number of villages and the population. By comparing these numbers with the population, it can be concluded that each county magistrate had to administer a rural population of 28,000, and each local administrator administered 8,000. The averages across the entire domain were 18,500 people per town or county magistrate and 6,650 people per local administrator.

These numbers indicate that in the Hiroshima domain, a small number of government officials were engaged in civil administration. In fact, five hundred thousand people were administered by just one hundred samurai, a proportion that would have made it difficult for those samurai to grasp the overall conditions of village communities. Such numbers further suggest, as I have argued in this chapter, how few samurai there were engaged in civil administration.

\section{The County Magistrate's Duties}

Having established the small number of samurai appointed to the civil administration, it is now time to address the question: What work did they actually have to do? To answer this, let us take a look at the mid-nineteenth-century work journal of a county magistrate of the Kurume domain,$^{30}$ which was located in Kyushu. The Kurume domain was ruled by the House of Arima, which occupied an area of two hundred thousand $k o k u$, and contained a population of about 250,00o people in 550 villages (Nishimura 1980). This work journal, which belonged to the county magistrate of Mizuma County ${ }^{31}$ in the Kurume domain, provides insight into his work. The journal begins with the names of eleven samurai who served as secretaries, treasurers, and village administrator ${ }^{32}$ before moving on to workrelated entries. According to the entries made by the county magistrate, he would hold meetings every winter with relevant subordinates to verify annual tribute collections and also meet with the village headmen's representatives. However, the journal does not contain detailed information about the collection of annual tributes, and while there is special mention of matters related to delayed payments of annual tribute to the ruler, this was limited to a minority of villages. This is probably because there was no need to write anything about prompt payments. 
The entries corresponding to visits from the village headmen's representatives are also exceedingly short, which gives the impression that they were more of a formality than a forum for the discussion of actual business.

Other than tribute-related items, there are many entries about (a) public order, the police, and lawsuits; and (b) participation in the ruler's formalities. The police mentioned in the (a) entries were a part of the civil administration and, needless to say, persons whose duty was indispensable for the safety of society. However, an independent police force served a large part of the Kurume domain, and within the villages there were also neighborhood watch-style groups headed by village headmen's representatives, which meant that the county magistrate did not necessarily oversee everything. Rather than general police functions, it may be more accurate to say that it was special investigations for which the police force in the (a) entries was responsible. In particular, special mention in the journal was given to the discovery and control of gambling, which was a prohibited activity and punishable offense at the time. Suspects were arrested by the subordinates of the county magistrate, who intervened on behalf of the local community. With the possibility that nonsamurai investigators (who were subordinate to the village headmen's representatives) would be partial to the suspects, it made sense for prosecutors to pursue a fair investigation by the county magistrate. Religious rites for the ruler and his ancestors and visits to Buddhist temples (item [b]) were also among the country magistrate's important duties. The county magistrate was also in charge of matters like public declarations of filial piety, which were carried out in domains across Japan during this time.

\section{THE DUTIES OF THE \\ SHOGUNATE'S CHIEF ADMINISTRATORS}

As suggested by the aforementioned numbers and roles of samurai appointed to organizations on the ruler's side, vassals were relatively unconcerned with civil administration. This section will discuss the activities of officials in the bakuryo, or lands under direct control of the Tokugawa shogunate, with the intention of comparing them to those of the domains discussed earlier.

There were pockets of bakuryō all over the country, with about forty of the shogunate's officials (hatamoto) appointed as chief administrators (bakufu dai$k a n),{ }^{33}$ who held de facto positions as leaders of their respective regions. These chief administrators were similar in stature to feudal lords, presiding over areas roughly equal in scale to those of minor daimyo; however, like the county directors and county magistrates of domains, they were also responsible for work related to civil administration.

Bakuryō in Kanto were presided over by chief administrators called Kanto daikan, whose office was established in Edo. Previous research on Kanto daikan has shown that they reported to work at this office more than three hundred days per 
year (Nishizawa 2004). This number varied in subsequent generations; there even appears to have been one instance where they reported to work in Edo 340 days out of the year. While such working conditions would seem to be rather cruel at first glance, normal working hours were from 10:00 AM to 2:00 PM, and sometimes they only had to work for two hours in the morning. It is supposed that their "desk work" consisted of duties such as communicating the shogunate's directives to the villages they governed, examining the reports received from villages, and offering judgments on individual court cases (Murakami 1970). However, judging by their working arrangement, it is difficult to imagine that their workload was very extensive; rather, it must have been quite light, at least most of the time.

The administrators of Nakano in Shinano province presided over one hundred villages in the bakuryo around their regional office (Nishizawa 2004). One might expect them to have worked and looked after their subjects from the regional office in Nakano, the local center of power. ${ }^{34}$ However, in Nakano, subordinates were stationed at the regional office; the administrators themselves lived in Edo. ${ }^{35}$ The extent of their visits to Nakano and the villages they governed was once a year in the fall-a mere twenty days' trip, of which ten were dedicated to village inspections. Though the goal of these trips was ostensibly the on-site verification of rice harvests, the mere fact of visiting as many as one hundred villages suggests that the administrators could not have conducted sufficient inspections. Ultimately their visits were nothing more than a formality.

\section{The Career of Itaro Hayashi}

Born in 1806 to the family of an official for the shogunate, Itaro Hayashi aspired to be a scholar (Murakami 1970, Yasuda 2009). Although Hayashi did become a scholar, he subsequently served as a chief administrator in many areas. At the beginning of the nineteenth century, the Tokugawa shogunate often appointed scholars to the post of chief administrator; other than Hayashi, however, nearly all of them resigned within the first year. ${ }^{36}$ In that regard, Hayashi was a rare individual who left the scholarly world and would go on to hold various positions in civil administration.

From 1858 to 1862, Hayashi was appointed as a local administrator for Shibahashi in Dewa Province (the northeast region of Japan called Tohoku, ten days on foot from Edo), where he presided over a bakuryō encompassing one hundred villages. The regional office was in Shibahashi, but only a few of his subordinates were stationed there. Meanwhile, Hayashi worked from his residence in Edo, which he himself owned. He visited the area he governed for about two weeks each year, which means that he was in Edo for the remaining 350 days. Of course, it would have been impossible for Hayashi to complete one year's work in two weeks and oversee all of the villages that he managed. In view of this fact, the local administrators worked as direct managers under his supervision. The number of local administrators who held a post in Shibahashi is uncertain; however, in 
Nakaizumi, where Hayashi began a new assignment, ${ }^{37}$ there were initially twentysix local administrators in 1853, and this number dropped to seventeen in 1858 . In any event, what kind of work did the feudal lord's administrative organization do, with only twenty samurai for an area where tens of thousands of people lived? Hayashi recorded daily events, which included the activities being conducted in Shibahashi at the time..$^{8}$ His journal contains an enormous amount of information, but evidence of interaction with commoners and detailed entries about the civil administration are rare.

Many of his office hours were spent creating and signing documents and making plans, with almost no activities involving positive interventions in village communities. However, inspecting the Shibahashi regional office over a period of two weeks seemed to be a hard schedule. He was accompanied by a subordinate and finished the inspection of a village on the first day. This indicates that the chief administrator's visit was just a formality - an item to be checked off the list without involving the actual work of inspecting the village. Moreover, while Hayashi was staying in Shibahashi, he also observed how a copper mine in the area under the shogunate's jurisdiction was being developed and managed; he subsequently developed that mining project further. Although there are entries about matters other than the development of the copper mine, there are few indications that he had developed innovative policies. He tackled a lawsuit and satisfactorily addressed an incident that occurred in the copper mine project. On the other hand, Hayashi hardly mentioned management of the village, and neither did his subordinate. This suggests that local administrators tasked peasants with management of the village, which was probably because annual tribute collection and other duties did not entail much work.

Hayashi's record of his daily activities adds two additional points to what we have learned about local administration from early examples. First, the local officer did not always reside in his administrative area. Hayashi performed on-site inspections only once a year; it is uncertain whether he actually fulfilled his duties as a member of the civil administration in the area he governed. Second, local officers had very few subordinates. In one example, there were twenty subordinates, and in another case, only ten people worked for one local officer. This was thought to be a small number, and it is surprising that a single officer could administer one hundred villages containing tens of thousands of people.

The smooth functioning of the civil administration in early modern Japan required the active participation of the peasants, particularly the village officials. Indeed, the peasants' contribution to local administration is a distinctive characteristic of the society during this period. On the other hand, the suzerain authority's limited employment of samurai in the civil administration clearly indicates that they did not assign it much importance. One could also argue that they had created a very 
effective system for local administration, incorporating commoners that worked very efficiently, so they did not need to employ more samurai. Furthermore, the few samurai who did hold posts in the civil administration were not deeply involved with the villages they ruled and rarely even visited them. The level of rulers' involvement in the human side of local governance was therefore extremely low with respect to their provision of public goods.

This chapter looked at the specific relationship between rulers and villages with regard to the staffing of the civil administration. Earlier research has shown that rural governance functioned smoothly with the help of peasants (muraukesei), ${ }^{39}$ but there has been little study of the staffing of administrative organizations.

As is evident from the appointment and roles of samurai in the Okayama and Hiroshima domains, not only did domains allocate only a small number of samurai to civil administration, but the samurai who were employed in that capacity did not live in the regions they ruled, severely limiting their opportunities to exercise their role as inspectors. It is not at all surprising, then, that such a state of affairs led to the active participation of a comparatively large number of village officials in civil administration. This is illustrated by the fact that the most salient tasks in the relationship between feudal lords and their subjects-conducting cadastral surveys and determining and collecting annual tributes-depended on the peasants. Moreover, in addition to the small proportion of samurai in civil administration compared to both vassal bands and the rural population, the civil administration's reliance on villages was also prompted by the rather light workloads of individual samurai.

Another major finding of this analysis, and one that may be regarded as another characteristic of early modern Japanese society, is the fact that peasants, who had to pay annual tributes, were not compensated by the load as employees.

\section{PRIMARY SOURCES}

Arimake Monjo (n.d.). Kōribugyō Nikki (The Country Magistrate's Journal), collection of Kurume City Main Library.

Takegaki Naomichi Nikki (The Journals of Takegaki Naomichi), in collection of Historiographical Institute of the University of Tokyo.

\section{NOTES}

1. For the details of annual tribute, see chapter 2 of this volume, by Masayuki Tanimoto.

2. The reforms of 1682 established the structure of village administration in the Okayama domain, which encompassed, for the most part, posts and hierarchy that were inherited by subsequent administrations (Taniguchi 1964).

3. These inspections were intended to inform subjects about ways to promote agricultural growth and to improve habits and customs.

4. The norm was for villages to nominate village officials and inform the county magistrate of the nominees, whom the magistrate would then appoint. 
5. There are data to indicate that there were 721 villages in 1868 and that the rural population of the domain was 366,867 in 1721 and 346,866 in 1834 (Kanai 1953).

6. This religious inquisition, the Shümon aratame, was the Edo shogunate's measure to ban Christianity and expose adherents. Families and individuals were asked about their religious affiliation (Buddhist sect) and had to prove that they were registered with a Buddhist temple. This information was recorded in the administrative documents.

7. Taniguchi (1964) states that local administrators treated the collection of tributes as their job, citing the "persuasion" of villages with declining production. However, it is unclear whether they actually collected the tributes.

8. The official titles of the Big Three varied from region to region and were sometimes changed over time, as in the case of the Okayama domain. In general, village headmen were called shoya, nanushi, or kimoiri; vice headmen were called toshiyori or kumigashira, and the peasants' representative was called hyakushōdai. Nevertheless, their respective job duties remained largely the same regardless of their title.

9. These two paths to assuming the post-by inheritance or by irefuda election-were the same in other domains as well. The vice headman could also be chosen by nomination of the village headman, in addition to either of those two methods.

10. For details of the koku, see the short introduction to part 1.

11. The village headmen's representative was called ojōya in the Okayama domain, but in other domains, other titles such as ökimori and warimoto were used.

12. Organizations of multiple villages were called kumi or kumiai.

13. The village headmen's representative was chosen from among the village headmen.

14. Surveys of lands belonging to the shogunate were usually conducted by officials from the shogunate, but for the Kanbun-Enpō survey, neighboring domains were put in charge in order to prevent fraud by officials from the shogunate and by the peasants under its rule (Mori 1970).

15. Surveyors measured the land's productivity and ranked each zone. In the beginning, there were three levels: high, medium, and low.

16. Cadasters were land registers upon which the collection of tributes was based. Each cadaster was created in duplicate; the original was kept by the feudal lord, and the copy was issued to the village (Kanzaki 1983).

17. This Kanei survey was the only time that the Sendai domain carried out its own cadastral survey across the lands under its jurisdiction.

18. Each group consisted of four samurai.

19. In general, newly developed fields were exempt from consideration in the collection of tributes for the first five years.

20. This corresponds to the Okayama domain's county magistrate.

21. It is unclear how the actual yields were determined, but there is no evidence that the county magistrate or other samurai were actively involved.

22. This corresponds to the Okayama domain's local administrators.

23. Popular movements such as peasant uprisings and village riots raised the caliber of officials (Kurushima 1995).

24. This figure includes the ruler's close attendants (his direct servants), rear vassals (their servants), servants of samurai households, and their families.

25. The number of close attendants was 385 in 1619, but subsequently increased (Doi 2015).

26. Their actual numbers for each section are unclear, but it is assumed that samurai were employed in proportion to the number of official posts.

27. The Hiroshima domain built residences in Edo, Kyoto, and Osaka, in which some samurai were stationed permanently.

28. These are the same posts as county magistrate and local administrator.

29. All of the numbers for area 1 pertain only to the villages around the castle town. For reference, the population of the castle town itself was about thirty thousand. 
30. Arimake Monjo n.d.

31. Mizuma County contained 130 villages and had a population of about fifty thousand.

32. These correspond to the local administrators. The county was divided into four regions, each governed by one administrator.

33. Chief administrators had greater authority than officials in the domain administration and often governed lands of between fifty thousand and one hundred thousand thousand koku. Some samurai inherited this post, whereas others were appointed by the domain and transferred to different regions, with the proportion of the latter increasing after the eighteenth century (Murakami 1970).

34. Regionally based chief administrators lived in buildings that housed both their private residences and the regional office.

35. Chief administrators had subordinates called tetsuki and tedai, of whom administrators generally had about twenty in total (Yasuda 2009).

36. There were many reasons, but ultimately, they were not cut out for politics, and it appears that the shogunate asked them to resign.

37. Prior to his appointment as an administrator for Shibahashi, Hayashi was an administrator for Nakaizumi in Tōtōmi province.

38. Yasuda 2003.

39. For details of the muraukesei, see the short introduction to part 1.

\section{REFERENCES}

Doi, Sakuji (2015). Hiroshima Han (The Hiroshima Domain). Yoshikawakōbunkan.

Hiroshima-ken (1973). Hiroshima-kenshi Kinseishiryōhen, vol. 1 (History of Hiroshima Prefecture, Early Modern Historical Materials, vol. 1). Hiroshima-ken.

- - (1984). Hiroshima-kenshi Tūshi, vol. 4 (History of Hiroshima Prefecture, vol. 4). Hiroshima-ken.

Kanai, Madoka (1953). "Hitotsu no han no sōjinkō" (Total Population of One Domain). Nihon-rekishi 67.

Kanzaki, Akitoshi (1983). Kenchi: Nawa to Sao no Shihai (The Land Survey: Rule to Be Established from a Rope and a Pole). Kyōikusha.

Kurushima, Hiroshi (1995). "Hyakushō to Mura no Henshitsu" (Change in Quality of a Farmer and the Village). In Iwanami Kōza Nihontūshi, vol. 15. Iwanami Shoten.

Morris, John Francis (2009). Kinsei Bushi no Kō to Shi: Sendaihanshi Tamamushi Jūzo no Kyaria to Zasetsu (The Public Job of the Samurai of Early Modern Japan, and a Private Life: Samurai of Sendai Career and Frustration which Tamamushi Jūzo Experiences). Seibundō Shuppan.

Mori, Sugio (1970). Enpō Kenchi (The Enpō Land Survey). Takaishi-shi Kyōdo-shi Kenkyūkai.

Murakami, Tadashi (1970). Edobakufu no Daikan (The Chief Administrator of the Edo Shogunate). Kokushokankōkai.

Nishimura, Mutsuo (1980). "Hanryōjinkō to Jōka-machijinkō" (The Domain Territory Population and Castle Town Population). Rekishi-chirigaku 111.

Nishizawa, Atsuo (2004). Daikan no Nichijōseikatsu: Edo no Chūkankanrishoku (A Local Governor's Everyday Life: The Middle Manager of the Edo Period). Kōdansha.

Ravina, Mark (1999). Land and Lordship in Early Modern Japan. Stanford University Press.

Sendai-shi (2001). Sendaishi-shi Tsūshihen, vol. 3 (History of Sendai City, vol. 3). Sendai-shi. 
Shirakawabe, Tatsuo (2010). Nihon Kinsei no Jiritsu to Rentai (Self-Support and Solidarity of Early Modern Japan). Tokyo Daigaku Shuppankai.

Taniguchi, Sumio (1964). Okayama Han (History of the Okayama Domain). Yoshikawakōbunkan.

Watanabe, Nobuo (1983). "Sendaihan no Seiritsu" (Establishment of the Sendai Domain). In Miyagi no Kenkyū, vol. 3. Seibundō Shuppan.

Watanabe, Takashi (1989). "Bakumatsuisinki Niokeru Nōmin to Sonrakukyōdōtai" (Peasants and Village Communities during the End of Edo and the Early Meiji Restoration Period). In Rekishi-hyōron 475.

- - (2004). "Mura no Sekai" (The World in a Village Community). In Nihon-shi Kōza, vol. 5. Tokyo Daigaku Shuppankai.

- - (2008). Hyakushō no Chikara: Edojidai kara Mieru Nippon (Peasant's Capability: Japan Seen from the Edo Period). Kashiwa Shobō.

_-_ (2010). Mura karamita Kinsei (Early Modern Japan as Seen from the Village). Azekura Shobō.

Yasuda, Haruo, ed. (2003). Hayashi Kakuryō Nikki, vol. 5 (The Journals of Hayashi Kakuryō). Nihon Hyōronsha.

-_- (2009). Aru Bunjindaikan no Bakumatsu Nikki (A Government Official Diary of Man of Culture). Yoshikawakōbunkan. 